\title{
Cell therapy of periodontium: from animal to human?
}

\author{
Elena A. Trofin ${ }^{1,2}$, Paul Monsarrat ${ }^{1,3 *}$ and Philippe Kémoun ${ }^{1}$ \\ ${ }^{1}$ Department of Biology, Toulouse Faculty of Dentistry - Paul Sabatier University, Toulouse University Hospital - CHU de Toulouse, Toulouse, France \\ 2 Department of Pathology, Faculty of Medicine and Odontology, University of Valencia, Valencia, Spain \\ ${ }^{3}$ Department of Public Health, Toulouse Faculty of Dentistry - Paul Sabatier University, Toulouse University Hospital - CHU de Toulouse, Toulouse, France
}

\section{Edited by:}

Jean-Christophe Farges, University

Lyon 1, France

\section{Reviewed by:}

Natalina Quarto, Università di Napoli

Federico II, Italy

Javier Catón, Universidad

Complutense de Madrid, Spain

*Correspondence:

Paul Monsarrat, Département de Biologie, Faculté de chirurgie

dentaire - Université Paul Sabatier 3,

chemin des maraîchers, 31062

Cedex 09 Toulouse, France

e-mail: paul.monsarrat@gmail.com
Periodontitis is a chronic inflammatory disease affecting the soft and hard tissues supporting the teeth, which often leads to tooth loss. Its significant impact on the patient's general health and quality of life point to a need for more effective management of this condition. Existing treatments include scaling/root planning and surgical approaches but their overall effects are relatively modest and restricted in application. The goal of regenerative therapy of periodontal defects is to enhance endogenous progenitors and thus promote optimal wound healing. Considering that the host or tissue might be defective in the periodontitis context, it has been proposed that grafting exogenous stem cells would produce new tissues and create a suitable microenvironment for tissue regeneration. Thus, cell therapy of periodontium has been assessed in many animal models and promising results have been reported. However, the methodological diversity of these studies makes the conversion to clinical practice difficult. The aim of this review is to highlight the primary requirements to be satisfied before the leap to clinical trials can be made. We therefore review cell therapy applications for periodontal regeneration in animal models and the concerns to be addressed before undertaking human experiments.

Keywords: mesenchymal stromal cells, periodontitis, tissue engineering, bone regeneration, clinical trials as topic

\section{INTRODUCTION}

Periodontitis is an immuno-infectious disease, characterized by loss of both the soft and hard tissues anchoring the teeth. Left untreated, it leads to tooth loss (Pihlstrom et al., 2005). Chronic periodontitis is found in $15-50 \%$ of adults in developed countries (Oliver et al., 1998; Bourgeois et al., 2005). Conventional treatment, including oral hygiene instructions, and scaling/root planing, aims to prevent the disease, or slow or stop its progress, and maintain the therapeutic goals achieved but is usually insufficient to promote the regeneration of damaged structures (Bosshardt and Sculean, 2009). Deep infrabony defects associated with periodontal pockets are the classic indication for surgical periodontal regenerative therapy (Ramseier et al., 2012). Nevertheless, outcomes of existing procedures [guided tissue regeneration (GTR), Enamel-Matrix Derivatives (EMD) or Platelet Rich Plasma (PRP)], are not predictable and are associated with a relatively high degree of variability (Needleman et al., 2006; Esposito et al., 2009).

The regenerative mechanisms of mesenchymal stromal cell (MSC) grafts include direct commitment toward differentiating cells together with paracrine communication with resident connective cells, and infiltration of inflammatory cells, antigenpresenting cells, or both (Sorrell and Caplan, 2010). Paracrine interactions require these cells to produce and respond to a variety of trophic factors that may stimulate the resident cells to differentiate and themselves renew the pathological tissue (Baraniak and McDevitt, 2010). In addition, MSCs also exhibit immuno-modulatory functions, making them a potential tool to combat an immuno-infectious disease such as periodontitis.
The reduction of inflammation by MSCs may halt the development of injury and allow regenerative processes to take place (Sensebe et al., 2010). Furthermore, MSCs may exert a neovascularization effect (Wu et al., 2007). Thus, one of the therapeutic functions of MSCs is the early induction of granulation tissue followed by the stabilization of the neovascular network in the periodontal niche (Sorrell and Caplan, 2010).

The graft of exogenous cells producing new tissues and/or making the local microenvironment suitable for an optimal activation of in-situ progenitors (Ilic and Polak, 2012; Shin and Peterson, 2013) has been tested in many models. Adult multipotent mesenchymal stromal cells, from bone marrow (BMSCs) or adipose tissue (adipose-derived stem cells or ASCs), are promising in the treatment of human diseases like graft-vs-host disease, ischemic cardiovascular diseases or large bone defects (Bourin et al., 2010; Sensebe et al., 2010). The main features of such cells include a capacity to self-renew and to undergo extensive proliferation and differentiation to various mesenchymal lineages (Dominici et al., 2006). Considering that the host or tissue might be defective in the periodontitis context, grafting exogenous MSCs that produce new tissues and create a suitable microenvironment for tissue regeneration has been proposed (Chen et al., 2012a). However, the methodological diversity of the available studies makes the conversion to clinical practice difficult. The aim of this review is, first, to report recent findings of periodontal regeneration in animal models and, second, to highlight the primary requirements to be satisfied before the leap to clinical trials can be made. 


\section{RESULTS FROM ANIMAL STUDIES}

Advances in mesenchymal stem cell isolation, growth factor biology, and biodegradable polymer constructs have set the stage for successful tissue engineering of the periodontium, basically in animal models. Our screening of the literature revealed that data were available for about fifty studies. The majority of them concerned periodontal defects generated mechanically (burs) on dogs and rodents. Except for nude rodents where xenogeneic cells were used, most studies used autologous cell grafts. Periodontal ligament stromal cells (PDLSCs) were employed in about half the studies.

Table 1 outlines the general methodology from recent papers investigating periodontal regeneration of various defect models in a range of large animals. These studies were selected both for their methodological quality and to reflect the heterogeneity of methodologies used. We voluntarily did not select studies on rodents because of the low similarity between their physiopathology and that of humans, although they are considered as essential models for preliminary protocols before moving on to largeanimal trials. Overall, the outcomes reported (Table 2) suggest that MSCs have the ability to enhance the regeneration of functional periodontal apparatus: newly formed bone and cementum with well-oriented ligament fibers.

\section{RESULTS FROM HUMAN STUDIES}

We identified 7 case reports (for a total of 22 patients) where MSCs had been applied clinically for infra-bony defects and furcation involvement after chronic periodontitis in humans. The efficacy of human periodontal cell therapy by grafting autologous stromal cells from gingiva or periodontal ligament with a hydroxyapatite (HA) carrier has been assessed since 1992 (Feng and Hou, 1992; Feng et al., 1995, 2010; Hou et al., 2003). Cultured mandibular periosteum-derived cell sheets with PRP have also been used in the treatment of chronic periodontitis without (Mizuno et al., 2010) or with HA in patients suffering from advanced chronic periodontitis (Okuda et al., 2009). A BMSCPRP gel has also been used in an infrabony periodontal defect and led to a $4 \mathrm{~mm}$ clinical attachment gain (Yamada et al., 2006). Results suggest promising improvements in pocket depth, attachment gain and tooth mobility, compared to control groups when present. These data suggest MSCs may induce efficient and safe periodontal regeneration in humans.

Through the International Clinical Trials Registry Platform (World Health Organization), we identified four clinical studies (last access 2013/08/27): two single-arm studies using (i) ASCs for 12 patients with deep infra-bony defects (recruiting) and (ii) a mixture of ex-vivo cultured MSCs and ex-vivo cultured osteoblast-like cells differentiated from MSCs for 10 patients with chronic periodontitis (completed); and two trials investigating the safety and efficacy of PDLSCs in chronic periodontitis, one randomized and one non-randomized controlled trial, with respectively 35 and 80 patients (recruiting).

Nevertheless, results from case reports and clinical trials should be interpreted with caution. Although the clinical potential of MSCs in tissue regeneration appears to be established, the mechanisms involved in these processes after transplantation are not clearly understood (Chen et al., 2012b; Hoogduijn and
Dor, 2013). Moreover, the clinical indications in periodontology remain be defined (Chen and Jin, 2010); the multiplicity of factors to be taken into account makes the regeneration equation more complex. Future studies should discuss regeneration according to the type of periodontal defects (number of walls), the type of periodontitis (chronic, aggressive) or the method used to generate the periodontitis model in animals, whether the MSCs are autologous, allogeneic or xenogeneic, the type of animal (dog, pig), the source tissue of MSCs (dental, oral, or extra-oral sources), the scaffold used, adjunctive growth factors or specific culture medium, etc.

\section{KEY ELEMENTS TO CONSIDER BEFORE MAKING THE STEP TO CLINICAL TRIALS}

The transfer of pre-clinical data to the clinical setting could be challenging and time consuming. So we will discuss some elements related to the choice of the origin of MSCs, their potential toxicity and their carrier, some laboratory considerations, the extent to which animal models reflect the applicability of the technique in humans, and regulatory information.

\section{CELL SOURCES}

One of the most important items of information that could help with the predictability of clinical results is the type of cell used. On the one hand, each tissue source has its own biological features and, even when they have common surface markers, these cells are determined by their original environment and may possibly be involved in specific differentiation pathways (Lin et al., 2009). On the other hand, the local microenvironment and surrounding tissue are important factors that influence the cell fate of whatever cells are ultimately used (Chen et al., 2011).

As stated above, PDLSCs are the cells most used for clinical trials, probably because of their periodontal origin and promising results in both animal and human trials (Feng et al., 2010; Suaid et al., 2012). Even if the choice of stromal cells from the oral niche (pulp, ligament, gingiva or oral alveolar bone) seems rational when the aim is to regenerate periodontal structures (Lin et al., 2009), periodontitis defects need a large number of cells (about $10^{7}$ cells are needed for one defect), which would be impossible to obtain from a single subject. Thus, the respect of ethical considerations (e.g., putative removal of healthy teeth, increasing genetic instability through passages during cellular expansion) requires other sources of MSCs to be sought.

Two major locations of available MSCs are long-bone marrow and adipose tissue. These cells are morphologically and immunophenotypically similar to PDLSCs (Huang et al., 2009). Unlike BMSCs, ASCs can be recovered easily in large numbers by means of liposuction under local anesthesia. Indeed, adipose tissue is the richest source of MSCs, 100 times more than bone marrow (Bourin et al., 2010). Although ASCs may exhibit a reduced ability to differentiate into bone and cartilage (Kern et al., 2006) compared to BMSC or oral mesenchymal cells, they have given promising results in periodontal regeneration in dogs (Takedachi et al., 2013; Tobita et al., 2013).

The need for high cell concentrations requires the optimal type of transplant to be determined. To become a clinical reality, xenografts need to overcome immunological, physiological, 


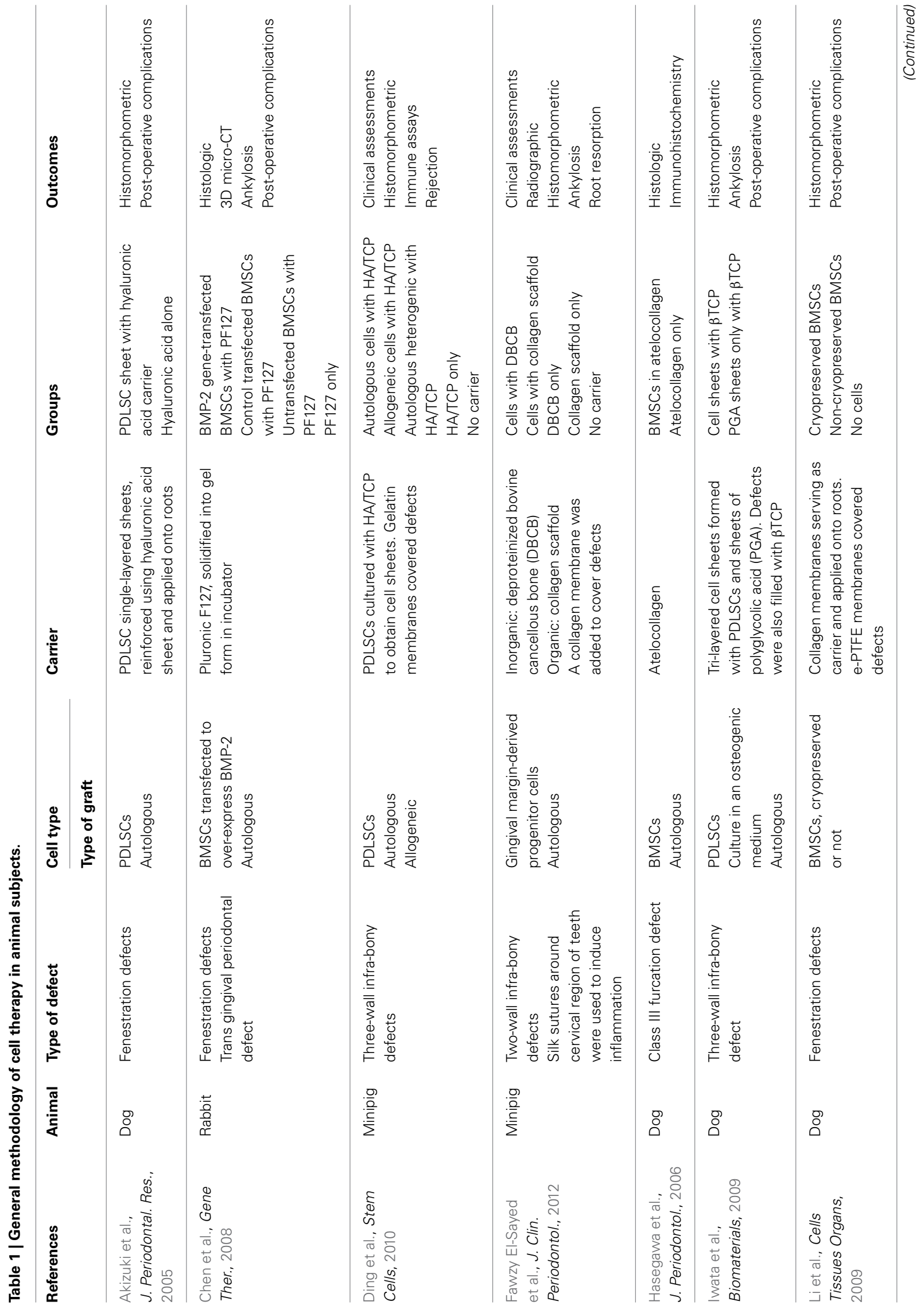




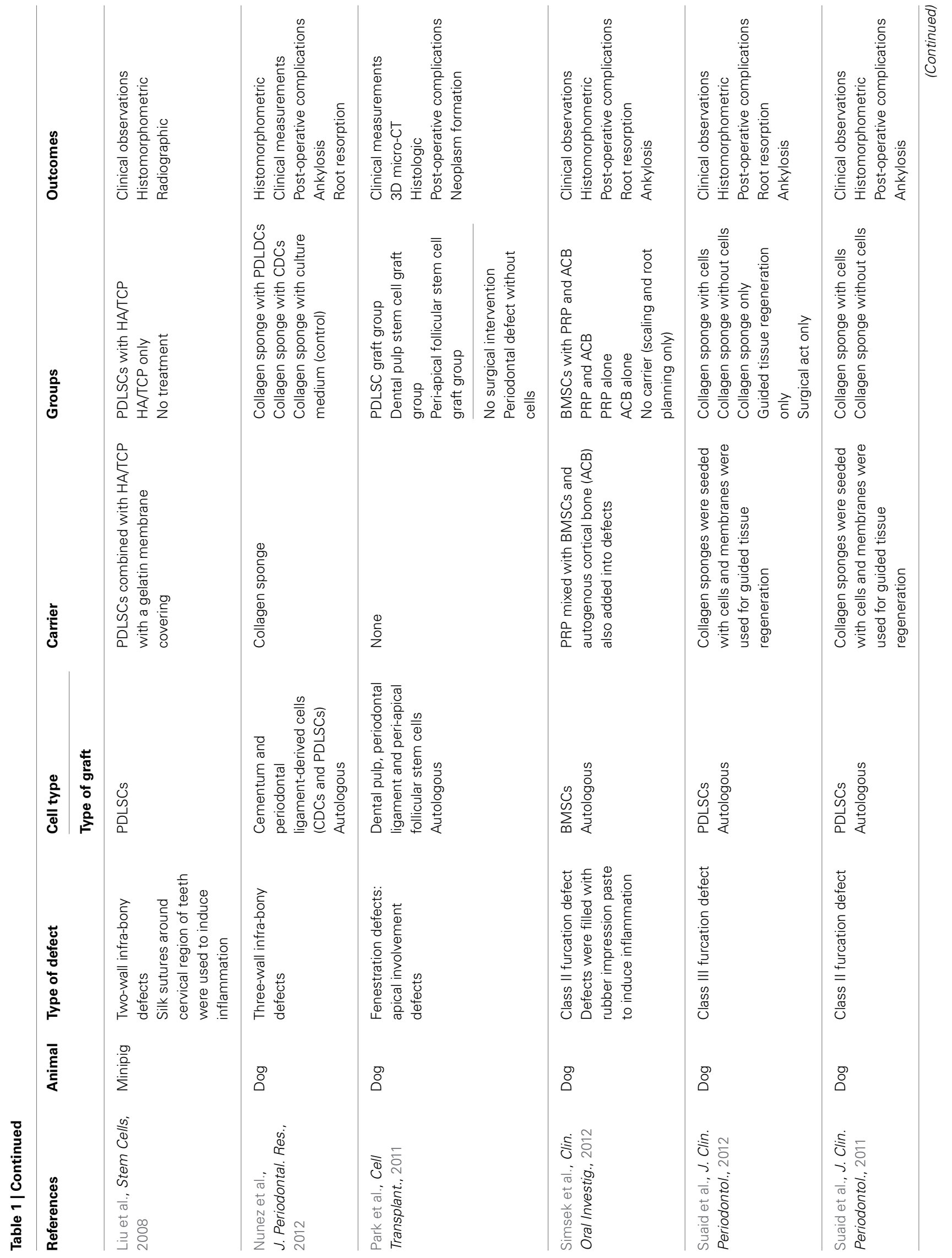


and infectious obstacles (Poncelet et al., 2009). For example, the donor might be genetically modified to protect its cells from the human immune system ( $\mathrm{Li}$ et al., 2012). MSCs are both immunosuppressive and immunoprivileged and, as such, may be used as an allogeneic source of cells. A recent randomized controlled trial showed significant benefits and low rates of immunologic reactions for transendocardial injection of allogenic BMSCs in patients with ischemic cardiomyopathy (Hare et al., 2012). Another limitation is the time required to produce the MSCs. Cell storage may be used to provide enough material at the time of graft. In a beagle dog, cryopreservation of BMSCs did not alter the periodontal regeneration compared to the use of non-stored cells (Li et al., 2009). However, additional studies are required to ensure the safety of allogenic grafts and cell cryopreservation.

\section{ADVERSE EFFECTS}

With population doublings during the expansion stage, MSCs may be subject to senescence and genetic instability. Progressive shortening of telomeres, modified telomeric structures, and activation of the retinoblastoma protein (pRB) or p53 pathways have been demonstrated to be important triggers for replicative senescence (Schellenberg et al., 2011). Basically, the role of MSCs in cancer can be divided into indirect involvement via the tumor modulatory effect and direct involvement via malignant transformation of themselves (Wong, 2011). The "homing" effect allows MSCs to migrate toward tumor cells, interact with the stroma, and enhance its growth (Wong, 2011). Also, it can lead to malignant transformation of MSCs at the tumor site. While the immunosuppressive properties of MSCs are a good tool for immune disorders, a suppressed immune system may encourage tumor growth in patients with cancer (Shinagawa et al., 2010). To date, no malignant formation has been reported during the course of clinical studies involving periodontal cell therapies (Giordano et al., 2007; Yoshida et al., 2012). Moreover, PDLSC did not induce tumorigenesis after injection into immunodeficient mice for at least 12 weeks (Washio et al., 2010). However, improvements in the understanding of genetic and epigenetic changes will enable researchers to address the risk of tumorigenesis in the context of each type of cell transplantation therapy.

\section{CELL CULTURE DURING LABORATORY PHASES}

The definition of MSCs as advanced-therapy medicinal products in European regulations and the US Food and Drug Administration requirements implies the use of production processes in accordance with Good Manufacturing Practices (GMPs). Requirements concern the environment, staff training and qualification, and controls (Sensebe et al., 2013). Culture conditions are not sufficiently developed to mimic the in-vivo cell microenvironment and to ensure that cell proliferation and differentiation can be performed safely (van der Sanden et al., 2010).

Cell culture status, such as culture medium composition and oxygen supply, may interact with MSC expansion and exvivo properties. Even though they are extensively described in studies, there is no consensus about the required culture conditions. Nevertheless, fetal calf serum (FCS), often used as a supplement, contains a xenogeneic source of growth factors and may transmit animal pathogens (Bourin et al., 2010). 
Table 2 | Results from animal studies.

\begin{tabular}{|c|c|c|c|}
\hline References & Experimental group outcomes & Control group outcomes & Conclusion \\
\hline $\begin{array}{l}\text { Akizuki et al., } \\
\text { J. Periodontal. Res., } 2005\end{array}$ & $\begin{array}{l}\text { Periodontal tissue healing with bone, } \\
\text { cementum, and periodontal ligament } \\
\text { formation was observed in three } \\
\text { defects. Signs of ankylosis were } \\
\text { observed in some specimens. }\end{array}$ & $\begin{array}{l}\text { No cementum was formed, only one } \\
\text { defect showed new bone. Parallel } \\
\text { connective tissue existed adjacent to } \\
\text { the denuded root surface. }\end{array}$ & $\begin{array}{l}\text { The periodontal ligament cell sheet } \\
\text { applied in a dehiscence-type defect } \\
\text { resulted in regeneration of periodontal } \\
\text { tissues in beagle dogs. }\end{array}$ \\
\hline
\end{tabular}

Chen et al., Gene Ther., 2008
BMP-2 gene-infected BMSCs Newly formed periodontal ligament fibers were functionally orientated and new connective tissue fibers had been inserted into both the new cementum and the new bone.

\section{BMSCs}

Woven bone was formed from apical part of defects to middle of the roots. There were small resorption areas with new cementum and fibers.
Regeneration of the periodontal attachment apparatus was enhanced by cells engineered to express BMP-2 gene.
Ding et al., Stem Cells, 2010
Both the autologous and allogeneic PDLSC treatments significantly improved periodontal tissue regeneration compared with the $\mathrm{HA} / \mathrm{TCP}$ and control groups. New bone, cementum, and periodontal ligament were regenerated to normal levels in both the autologous and allogeneic PDLSC groups.
Fawzy El-Sayed et al., J. Clin. Periodontol., 2012
Higher clinical attachment level, probing depth and lower gingival recession. Thin multi-layered squamous sulcular epithelium. Regeneration of bone, cementum, and periodontal ligament with Sharpey's fibers similar to normal periodontium.

Higher histological attachment level, lower junctional epithelium length, and connective tissue adhesion.
Hasegawa et al., J. Periodontol., 2006

\section{New cementum.}

New regenerated periodontal ligament separating the new bone from the cementum.

No complete alveolar bone reconstruction.
Limited or partial periodontal tissue regeneration in the control groups and HA/TCP group.

Little alveolar bone recovery.
A sheet of minipig PDLSCs can repair allogeneic bone defects in an experimental model of periodontitis.
Complete bone filling with an appropriate space of periodontal ligament was observed. Complete periodontal regeneration with both newly formed bone and cementum connecting with well-oriented collagen fibers.

Li et al., Cells Tissues Organs, 2009
Both cryo- and non-cryopreserved BMSC groups exhibited periodontal regeneration. New PDL was formed between the new alveolar bone and cementum with Sharpey's fibers extending into the newly formed cementum and bone. Cementum and PDL were fully regenerated.
Thicker multi-layered squamous sulcular epithelium.

Periodontal tissue loss, unorganized Sharpey's fibers, root resorption, and ankylosis.
Gingival margin-derived stem/progenitor cells show significant periodontal regenerative potential.
Insufficient periodontal regeneration. Epithelial cells invading top of the furcation, and no cementum regeneration.
Transplanted BMSCs can survive and differentiate into periodontal tissue-composing cells, resulting in enhancement of periodontal tissue regeneration.
Almost $50 \%$ of bone filling was observed.
Transplantable multi-layered PDLSC cell sheets were successfully fabricated and induced a true periodontal system, including alveolar bone, cementum, and well-oriented fibers at the same time.
Very little regenerated alveolar bone and cementum.

PDL fibers were parallel to the root surface. Small lacunae of resorption were present on roots.
Cryopreserved BMSCs showed no altered regenerative capacity compared with freshly isolated BMSCs in the application of periodontal regeneration. 
Table 2 | Continued

\begin{tabular}{|c|c|c|c|}
\hline References & Experimental group outcomes & Control group outcomes & Conclusion \\
\hline $\begin{array}{l}\text { Liu et al., Stem Cells, } \\
2008\end{array}$ & $\begin{array}{l}\text { New bone and periodontal tissues } \\
\text { were regenerated with newly formed } \\
\text { Sharpey's fibers anchored into the } \\
\text { newly regenerated cementum. } \\
\text { Nevertheless, bone was not } \\
\text { regenerated to normal level. }\end{array}$ & $\begin{array}{l}\text { Fibers lacking the typical structure of } \\
\text { Sharpey's fibers filled in the } \\
\text { periodontal defect. Residual } \\
\text { inflammation was still present. }\end{array}$ & $\begin{array}{l}\text { The study demonstrated the utility of } \\
\text { using an autologous PDLSC } \\
\text { therapeutic approach to treat } \\
\text { periodontitis in a miniature pig } \\
\text { preclinical model. }\end{array}$ \\
\hline $\begin{array}{l}\text { Nunez et al., } \\
\text { J. Periodontal. Res., } 2012\end{array}$ & $\begin{array}{l}\text { Histological characteristics of } \\
\text { periodontal regeneration: formation of } \\
\text { new cellular cementum, no signs of } \\
\text { root resorption or ankylosis, rich } \\
\text { capillary vessels. } \\
\text { Greater new-bone formation in the } \\
\text { PDLDC group. }\end{array}$ & $\begin{array}{l}\text { Healing by repair, with limited } \\
\text { formation of new cellular cementum. } \\
\text { No signs of root resorption or } \\
\text { ankylosis. }\end{array}$ & $\begin{array}{l}\text { Cellular therapy, in combination with a } \\
\text { collagen sponge, promoted } \\
\text { periodontal regeneration in } \\
\text { experimental infra-bony periodontal } \\
\text { defects. }\end{array}$ \\
\hline
\end{tabular}

Park et al., Cell

Transplant., 2011
Healing response was favorable for all treatment groups. For PDLSC group, incremental lines of neocementum were observed, with Sharpey's fibers inserted and cellular cementum at the root apex.
No tissue attachment but presence of surrounding granulation.
PDLSCs may significantly promote periodontal regeneration in class II furcation defects in dogs. Authors suggested PDLSCs were the best candidates for regeneration.
Simsek et al., Clin. Oral Investig., 2012
Formation of new cementum and coronal growth of alveolar bone were observed in all groups. No root resorption or ankylosis was present. No efficacy difference between the groups was found for alveolar bone formation. There was no severe inflammation or swelling and dehiscence of the flaps. Regeneration of cementum for cell group was significantly higher than control group.
Suaid et al., J. Clin. Periodontol., 2011
Woven bone was predominant. In all groups, new cementum and obliquely oriented periodontal fibers were regenerated. Ankylosis was present in one specimen for each group. Nevertheless, cell group presented more new cementum surface, less connective tissue and epithelium along root surface, more bone area than control group.
Suaid et al., J. Clin. Periodontol., 2012

Cell-treated group exhibited larger area of new bone, more cementum, and more periodontal regeneration than other groups. Complete filling of the furcation was achieved in 2 out of 6 defects.

Takedachi et al., J. Oral Biosci., 2013
Compared to control, bone mineral density increased in 2-wall defects. New bone and new cementum were formed, with connective tissue fibers inserted vertically in the furcation class II defect.
Large bone marrow spaces were predominant. Down-growth of epithelium was observed in some histological sections.
Periodontal regeneration with complete filling of class II furcation defects with cementum, alveolar bone, and periodontal ligament was obtained for all groups compared to control group.
All defects showed gingival recession with exposure of the furcation area. Defects were incompletely filled, with inflamed connective tissue covered by gingival epithelium. There was no cementum covering entire root area.
PDLSCs with guided tissue regeneration were shown to be efficient for periodontal regeneration in class II furcation defects.
PDLSCs in association with guided tissue regeneration may significantly promote periodontal regeneration in class III furcation defects surgically created in dogs.
A mix of ASCs and fibrin gel promoted periodontal regeneration in beagle dogs. 
Table 2 | Continued

\begin{tabular}{llll}
\hline References & Experimental group outcomes & Control group outcomes & Conclusion \\
\hline $\begin{array}{l}\text { Tobita et al., Cytotherapy, } \\
2013\end{array}$ & $\begin{array}{l}\text { New bone was formed and } \\
\text { periodontal complex was regenerated } \\
\text { after 2 months. Osteocalcin-positive } \\
\text { cells were found on the surface of the } \\
\text { dentin. }\end{array}$ & $\begin{array}{l}\text { Ingrowth of epithelium into the defect } \\
\text { was found in the non-implanted } \\
\text { group. Granular tissue and } \\
\text { radiolucency were observed in both } \\
\text { control groups. }\end{array}$ & $\begin{array}{l}\text { Efficacy of the combination of ASCs } \\
\text { and PRP in canine periodontal tissue } \\
\text { regeneration. }\end{array}$ \\
\hline $\begin{array}{ll}\text { Tsumanuma et al., } \\
\text { Biomaterials, 2011 }\end{array}$ & $\begin{array}{l}\text { PDLSC group showed more cellular } \\
\text { and acellular cementum than other } \\
\text { groups. Dense collagen fibers were } \\
\text { perpendicularly attached to the } \\
\text { cementum-like tissue layer. In BMSC } \\
\text { group, fibers were obliquely oriented } \\
\text { whereas they were parallel in APC }\end{array}$ & $\begin{array}{l}\text { Alveolar bone regeneration was } \\
\text { observed in all groups. }\end{array}$ & $\begin{array}{l}\text { PDLSC sheets combined with } \beta \text {-TCP } \\
\text { and collagen induced more } \\
\text { periodontal regeneration than in other } \\
\text { groups. }\end{array}$ \\
& & &
\end{tabular}

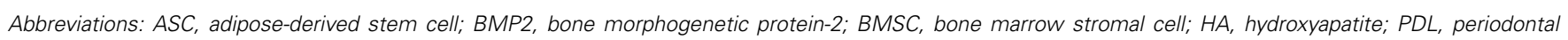
ligament; PDLSC, periodontal ligament stromal cell; TCP, tricalcium phosphate.

Addition of human blood-derived products to replace FCS is secured by serologic and nuclear acid testing for bloodtransmitted viruses. Human platelet lysate, a blood plasma enriched in platelet growth factors released by freezing-thawing cycles, may be used to produce clinical-grade, stem-cell-loaded biomaterials as an appropriate FCS substitute in line with clinically applicable practice (Warnke et al., 2013). Various other serum-free media based on mixtures of defined growth factors are also able to maintain the main phenotypic and functional characteristics of cultured MSCs (Chase et al., 2010) but are restricted to research purposes and require upgrading for clinical uses.

\section{USE OF CARRIER AND GROWTH FACTORS}

In the review of the literature on periodontal regeneration by MSCs, one of the most striking elements is the numerous carriers that have been used. Cortical bone particulates (Simsek et al., 2012), bovine bone (Fawzy El-Sayed et al., 2012), HA (Ding et al., 2010), polymers (Park et al., 2012), collagen (Suaid et al., 2011), hydrogel (Wei et al., 2010), gelatin (Yang et al., 2010), fibrinogen/thrombin (Hynes et al., 2013), PRP (Tobita et al., 2013), cells as sheets (Tsumanuma et al., 2011), alone or in combination, have been suggested to help cell grafting. The heterogeneity among study methodologies makes it difficult to compare them and to draw sound conclusions. Biomolecules, in particular growth factors, have been suggested for addition to scaffolds to enhance periodontal regeneration (Saito et al., 2009). It has been reported that modified MSCs overexpressing growth factors such as BMP-2 (Chen et al., 2008; Chung et al., 2011) or bFGF (Tan et al., 2009) could improve the healing of periodontal defects by maintaining a long-term release of these factors in situ (Ramseier et al., 2012).

\section{PERIODONTITIS MODELS IN ANIMALS}

Non-human primates are similar to humans, with comparable periodontal tissue structures. However, most non-human primates used for research purposes are expensive and difficult to handle, and ethical restrictions apply to their exploitation (Struillou et al., 2010). The beagle is one of the most commonly used due to its size and its cooperative temperament (Haney et al., 1995; Struillou et al., 2010). Minipigs are also an alternative (Fawzy El-Sayed et al., 2012). However, animal models are unable to mimic some fundamental features: the spontaneous emergence of disease (even though some periodontal lesions can occur in aged animals, periodontal defects are mostly mechanically generated), genetic background, and risk factors (aggressive bacterial flora, occlusal overload, tobacco, prosthesis, systemic diseases of host, and donor, etc.). Overall, these features should be investigated when clinical trials are being designed and analyzed.

\section{REGULATORY INFORMATION}

The translation of a cell-based therapy from bench to bedside is challenging, in a regulatory framework involving multiple responsible authorities. Japan, Europe, and the United States have developed quality standards to regulate cell based therapies with Good Clinical Practice and GMP (Yoshida et al., 2012). In the USA, MSCs are considered in the context of "361 Human Cells, Tissues, or Cellular and Tissue-Based Products” (source: www.fda.gov). For European countries, the framework for human trials is fixed by regulation number 1394/2007 on advanced therapy medicinal products, in force since December 2008.

The clinical development plan should start with the submission of a clinical trial authorization application to the competent authority; clinical trials should be designed to demonstrate the safety and efficacy of cells (George, 2011). It can be noted that, in 2006, the WHO stated that all clinical trials should be registered. Moreover, US federal law (Food and Drug Administration) recommends the registration of trials via clinicaltrials.gov to record key elements of study and basic results, and to report adverse events (Califf et al., 2012).

In first-in-man studies, specific safety endpoints may need to be defined to explore: cross-contamination in cases of allogeneic and xenogeneic graft, chromosomal stability, contamination with 
microorganisms, safety of engineering devices, stemness potential, functional characterization, and cell phenotype (Dittmar et al., 2010). Because of the risk-benefit balance in periodontal regeneration, emphasis should be placed on the safety of these therapeutics.

\section{CONCLUSION}

Animal studies suggest that mesenchymal stem cells are effective and safe for periodontal regeneration. Nevertheless, additional studies are needed to improve periodontal cell therapy regeneration and to decipher the biological mechanisms that are involved. For example, a recent study in dogs suggested that periodontal regeneration could be obtained with stem-cell conditioned medium, possibly thanks to multiple cytokines (Inukai et al., 2013). To materialize the translation of cell therapy from the laboratory to the dental chair a compromise, providing real benefits for patients, respecting biosafety requirements, available at affordable prices, covered by a social security system and sufficiently attractive to encourage industrial companies to invest in its development, is still required. It is possible that cell therapy will be implemented in clinical practice as a routine technique in the future.

\section{ACKNOWLEDGMENTS}

This study was supported by internal funding from the University of Toulouse, the Toulouse Faculty of Dentistry, Paul Sabatier University, and Toulouse University Hospital. All authors participated in writing manuscript. The authors thank Susan Becker for proofreading the manuscript.

\section{REFERENCES}

Akizuki, T., Oda, S., Komaki, M., Tsuchioka, H., Kawakatsu, N., Kikuchi, A., et al. (2005). Application of periodontal ligament cell sheet for periodontal regeneration: a pilot study in beagle dogs. J. Periodontal. Res. 40, 245-251. doi: 10.1111/j.1600-0765.2005.00799.x

Baraniak, P. R., and McDevitt, T. C. (2010). Stem cell paracrine actions and tissue regeneration. Regen. Med. 5, 121-143. doi: 10.2217/rme.09.74

Bosshardt, D. D., and Sculean, A. (2009). Does periodontal tissue regeneration really work? Periodontol. 2000 51, 208-219. doi: 10.1111/j.16000757.2009.00317.x

Bourgeois, D., Llodra, J., Nordblad, A., and Pitts, N. (2005). "Health surveillance in Europe-a selection of essential oral health indicators," in Technical Report, European Global Oral Health Development Project (EGOHID), Lyon.

Bourin, P., Sensebé, L., Planat-Bénard, V., Roncalli, J., Bura-Rivière, A., and Casteilla, L. (2010). Culture and use of mesenchymal stromal cells in phase I and II clinical trials. Stem Cells Int. 2010, 503593. doi: 10.4061/2010/503593

Califf, R. M., Zarin, D. A., Kramer, J. M., Sherman, R. E., Aberle, L. H., and Tasneem, A. (2012). Characteristics of clinical trials registered in ClinicalTrials.gov, 2007-2010. JAMA 307, 1838-1847. doi: 10.1001/jama.2012. 3424

Chase, L. G., Lakshmipathy, U., Solchaga, L. A., Rao, M. S., and Vemuri, M. C. (2010). A novel serum-free medium for the expansion of human mesenchymal stem cells. Stem Cell Res. Ther. 1, 8. doi: 10.1186/scrt8

Chen, F. M., and Jin, Y. (2010). Periodontal tissue engineering and regeneration: current approaches and expanding opportunities. Tissue Eng. Part B Rev. 16, 219-255. doi: 10.1089/ten.teb.2009.0562

Chen, F. M., Sun, H. H., Lu, H., and Yu, Q. (2012a). Stem cell-delivery therapeutics for periodontal tissue regeneration. Biomaterials 33, 6320-6344. doi: 10.1016/j.biomaterials.2012.05.048

Chen, J. S., Wong, V. W., and Gurtner, G. C. (2012b). Therapeutic potential of bone marrow-derived mesenchymal stem cells for cutaneous wound healing. Front. Immunol. 3:192. doi: 10.3389/fimmu.2012.00192
Chen, F. M., Wu, L. A., Zhang, M., Zhang, R., and Sun, H. H. (2011). Homing of endogenous stem/progenitor cells for in situ tissue regeneration: promises, strategies, and translational perspectives. Biomaterials 32, 3189-3209. doi: 10.1016/j.biomaterials.2010.12.032

Chen, Y. L., Chen, P. K., Jeng, L. B., Huang, C. S., Yang, L. C., Chung, H. Y., et al. (2008). Periodontal regeneration using ex vivo autologous stem cells engineered to express the BMP-2 gene: an alternative to alveolaplasty. Gene Ther. 15, 1469-1477. doi: 10.1038/gt.2008.131

Chung, V. H., Chen, A. Y., Kwan, C. C., Chen, P. K., and Chang, S. C. (2011). Mandibular alveolar bony defect repair using bone morphogenetic protein 2expressing autologous mesenchymal stem cells. J. Craniofac. Surg. 22, 450-454. doi: 10.1097/SCS.0b013e3182077de9

Ding, G., Liu, Y., Wang, W., Wei, F., Liu, D., Fan, Z., et al. (2010). Allogeneic periodontal ligament stem cell therapy for periodontitis in swine. Stem Cells 28, 1829-1838. doi: 10.1002/stem.512

Dittmar, K. E., Simann, M., Zghoul, N., Schön, O., Meyring, W., Hannig, H., et al. (2010). Quality of cell products: authenticity, identity, genomic stability and status of differentiation. Transfus. Med. Hemother. 37, 57-64. doi: 10.1159/000284401

Dominici, M., Le Blanc, K., Mueller, I., Slaper-Cortenbach, I., Marini, F., Krause, D., et al. (2006). Minimal criteria for defining multipotent mesenchymal stromal cells. the international society for cellular therapy position statement. Cytotherapy 8, 315-317. doi: 10.1080/14653240600855905

Esposito, M., Grusovin, M. G., Papanikolaou, N., Coulthard, P., and Worthington, H. V. (2009). Enamel matrix derivative (Emdogain $(R))$ for periodontal tissue regeneration in intrabony defects. Cochrane Database Syst. Rev. 7:CD003875. doi: 10.1002/14651858.CD003875.pub3

Fawzy El-Sayed, K. M., Paris, S., Becker, S. T., Neuschl, M., De Buhr, W., Salzer, S., et al. (2012). Periodontal regeneration employing gingival margin-derived stem/progenitor cells: an animal study. J. Clin. Periodontol. 39, 861-870. doi: 10.1111/j.1600-051X.2012.01904.x

Feng, F., Akiyama, K., Liu, Y., Yamaza, T., Wang, T. M., Chen, J. H., et al. (2010). Utility of PDL progenitors for in vivo tissue regeneration: a report of 3 cases. Oral Dis. 16, 20-28. doi: 10.1111/j.1601-0825.2009.01593.x

Feng, F., and Hou, L. T. (1992). Treatment of osseous defects with fibroblast-coated hydroxylapatite particles. J. Formos. Med. Assoc. 91, 1068-1074.

Feng, F., Liu, C. M., Hsu, W. C., and Hou, L. T. (1995). Long-term effects of gingival fibroblast-coated hydroxylapatite graft on periodontal osseous defects. J. Formos. Med. Assoc. 94, 494-498.

George, B. (2011). Regulations and guidelines governing stem cell based products: clinical considerations. Perspect. Clin. Res. 2, 94-99. doi: 10.4103/22293485.83228

Giordano, A., Galderisi, U., and Marino, I. R. (2007). From the laboratory bench to the patient's bedside: an update on clinical trials with mesenchymal stem cells. J. Cell. Physiol. 211, 27-35. doi: 10.1002/jcp.20959

Haney, J. M., Zimmerman, G. J., and Wikesjo, U. M. (1995). Periodontal repair in dogs: evaluation of the natural disease model. J. Clin. Periodontol. 22, 208-213. doi: 10.1111/j.1600-051X.1995.tb00136.x

Hare, J. M., Fishman, J. E., Gerstenblith, G., Difede Velazquez, D. L., Zambrano, J. P., Suncion, V. Y., et al. (2012). Comparison of allogeneic vs autologous bone marrow-derived mesenchymal stem cells delivered by transendocardial injection in patients with ischemic cardiomyopathy: the POSEIDON randomized trial. JAMA 308, 2369-2379. doi: 10.1001/jama.2012.25321

Hasegawa, N., Kawaguchi, H., Hirachi, A., Takeda, K., Mizuno, N., Nishimura, M., et al. (2006). Behavior of transplanted bone marrow-derived mesenchymal stem cells in periodontal defects. J. Periodontol. 77, 1003-1007. doi: 10.1902/jop.2006.050341

Hoogduijn, M. J., and Dor, F. J. (2013). Mesenchymal stem cells: are we ready for clinical application in transplantation and tissue regeneration? Front. Immunol. 4:144. doi: 10.3389/fimmu.2013.00144

Hou, L. T., Tsai, A. Y., Liu, C. M., and Feng, F. (2003). Autologous transplantation of gingival fibroblast-like cells and a hydroxylapatite complex graft in the treatment of periodontal osseous defects: cell cultivation and longterm report of cases. Cell Transplant. 12, 787-797. doi: 10.3727/000000003108 747262

Huang, G. T., Gronthos, S., and Shi, S. (2009). Mesenchymal stem cells derived from dental tissues vs. those from other sources: their biology and role in regenerative medicine. J. Dent. Res. 88, 792-806. doi: 10.1177/0022034509 340867 
Hynes, K., Menicanin, D., Han, J., Marino, V., Mrozik, K., Gronthos, S., et al. (2013). Mesenchymal stem cells from iPS cells facilitate periodontal regeneration. J. Dent. Res. 92, 833-839. doi: 10.1177/0022034513498258

Ilic, D., and Polak, J. (2012). Stem cell based therapy-where are we going? Lancet 379, 877-878. doi: 10.1016/S0140-6736(12)60155-X

Inukai, T., Katagiri, W., Yoshimi, R., Osugi, M., Kawai, T., Hibi, H., et al. (2013). Novel application of stem cell-derived factors for periodontal regeneration. Biochem. Biophys. Res. Commun. 430, 763-768. doi: 10.1016/j.bbrc.2012. 11.074

Iwata, T., Yamato, M., Tsuchioka, H., Takagi, R., Mukobata, S., Washio, K., et al. (2009). Periodontal regeneration with multi-layered periodontal ligamentderived cell sheets in a canine model. Biomaterials 30, 2716-2723. doi: 10.1016/j.biomaterials.2009.01.032

Kern, S., Eichler, H., Stoeve, J., Kluter, H., and Bieback, K. (2006). Comparative analysis of mesenchymal stem cells from bone marrow, umbilical cord blood, or adipose tissue. Stem Cells 24, 1294-1301. doi: 10.1634/stemcells. 2005-0342

Li, H., Yan, F., Lei, L., Li, Y., and Xiao, Y. (2009). Application of autologous cryopreserved bone marrow mesenchymal stem cells for periodontal regeneration in dogs. Cells Tissues Organs 190, 94-101. doi: 10.1159/000166547

Li, J., Ezzelarab, M. B., and Cooper, D. K. (2012). Do mesenchymal stem cells function across species barriers? Relevance for xenotransplantation. Xenotransplantation 19, 273-285. doi: 10.1111/xen.12000

Lin, N. H., Gronthos, S., and Mark Bartold, P. (2009). Stem cells and future periodontal regeneration. Periodontol. 2000 51, 239-251. doi: 10.1111/j.16000757.2009.00303.x

Liu, Y., Zheng, Y., Ding, G., Fang, D., Zhang, C., Bartold, P. M., et al. (2008). Periodontal ligament stem cell-mediated treatment for periodontitis in miniature swine. Stem Cells 26, 1065-1073. doi: 10.1634/stemcells. 2007-0734

Mizuno, H., Kagami, H., Mase, J., Mizuno, D., and Ueda, M. (2010). Efficacy of membranous cultured periosteum for the treatment of patients with severe periodontitis: a proof-of-concept study. Nagoya J. Med. Sci. 72, 59-70.

Needleman, I. G., Worthington, H. V., Giedrys-Leeper, E., and Tucker, R. J. (2006). Guided tissue regeneration for periodontal infra-bony defects. Cochrane Database Syst. Rev. 19:CD001724. doi: 10.1002/14651858.CD001724.pub2

Nunez, J., Sanz-Blasco, S., Vignoletti, F., Munoz, F., Arzate, H., Villalobos, C., et al. (2012). Periodontal regeneration following implantation of cementum and periodontal ligament-derived cells. J. Periodontal. Res. 47, 33-44. doi: 10.1111/j.1600-0765.2011.01402.x

Okuda, K., Yamamiya, K., Kawase, T., Mizuno, H., Ueda, M., and Yoshie, H. (2009). Treatment of human infrabony periodontal defects by grafting human cultured periosteum sheets combined with platelet-rich plasma and porous hydroxyapatite granules: case series. J. Int. Acad. Periodontol. 11, 206-213.

Oliver, R. C., Brown, L. J., and Loe, H. (1998). Periodontal diseases in the United States population. J. Periodontol. 69, 269-278. doi: 10.1902/jop.1998.69.2.269

Park, C. H., Rios, H. F., Jin, Q., Sugai, J. V., Padial-Molina, M., Taut, A. D., et al. (2012). Tissue engineering bone-ligament complexes using fiber-guiding scaffolds. Biomaterials 33, 137-145. doi: 10.1016/j.biomaterials.2011.09.057

Park, J. Y., Jeon, S. H., and Choung, P. H. (2011). Efficacy of periodontal stem cell transplantation in the treatment of advanced periodontitis. Cell Transplant. 20, 271-285. doi: 10.3727/096368910X519292

Pihlstrom, B. L., Michalowicz, B. S., and Johnson, N. W. (2005). Periodontal diseases. Lancet 366, 1809-1820. doi: 10.1016/S0140-6736(05)67728-8

Poncelet, A. J., Denis, D., and Gianello, P. (2009). Cellular xenotransplantation. Curr. Opin. Organ Transplant. 14, 168-174. doi: 10.1097/MOT.0b013e3283292522

Ramseier, C. A., Rasperini, G., Batia, S., and Giannobile, W. V. (2012). Advanced reconstructive technologies for periodontal tissue repair. Periodontol. 2000 59, 185-202. doi: 10.1111/j.1600-0757.2011.00432.x

Saito, A., Saito, E., Handa, R., Honma, Y., and Kawanami, M. (2009). Influence of residual bone on recombinant human bone morphogenetic protein-2-induced periodontal regeneration in experimental periodontitis in dogs. J. Periodontol. 80, 961-968. doi: 10.1902/jop.2009.080568

Schellenberg, A., Lin, Q., Schuler, H., Koch, C. M., Joussen, S., Denecke, B., et al. (2011). Replicative senescence of mesenchymal stem cells causes DNAmethylation changes which correlate with repressive histone marks. Aging (Albany NY) 3, 873-888.
Sensebe, L., Gadelorge, M., and Fleury-Cappellesso, S. (2013). Production of mesenchymal stromal/stem cells according to good manufacturing practices: a review. Stem Cell Res. Ther. 4, 66. doi: 10.1186/scrt217

Sensebe, L., Krampera, M., Schrezenmeier, H., Bourin, P., and Giordano, R. (2010). Mesenchymal stem cells for clinical application. Vox Sang. 98, 93-107. doi: 10.1111/j.1423-0410.2009.01227.x

Shin, L., and Peterson, D. A. (2013). Human mesenchymal stem cell grafts enhance normal and impaired wound healing by recruiting existing endogenous tissue stem/progenitor cells. Stem Cells Transl. Med. 2, 33-42. doi: 10.5966/sctm. 2012-0041

Shinagawa, K., Kitadai, Y., Tanaka, M., Sumida, T., Kodama, M., Higashi, Y., et al. (2010). Mesenchymal stem cells enhance growth and metastasis of colon cancer. Int. J. Cancer 127, 2323-2333. doi: 10.1002/ijc.25440

Simsek, S. B., Keles, G. C., Baris, S., and Cetinkaya, B. O. (2012). Comparison of mesenchymal stem cells and autogenous cortical bone graft in the treatment of class II furcation defects in dogs. Clin. Oral Investig. 16, 251-258. doi: 10.1007/s00784-010-0486-7

Sorrell, J. M., and Caplan, A. I. (2010). Topical delivery of mesenchymal stem cells and their function in wounds. Stem Cell Res. Ther. 1, 30. doi: 10.1186/scrt30

Struillou, X., Boutigny, H., Soueidan, A., and Layrolle, P. (2010). Experimental animal models in periodontology: a review. Open Dent. J. 4, 37-47. doi: $10.2174 / 1874210601004010037$

Suaid, F. F., Ribeiro, F. V., Gomes, T. R., Silverio, K. G., Carvalho, M. D., Nociti, F. H. Jr., et al. (2012). Autologous periodontal ligament cells in the treatment of Class III furcation defects: a study in dogs. J. Clin. Periodontol. 39, 377-384. doi: 10.1111/j.1600-051X.2012.01858.x

Suaid, F. F., Ribeiro, F. V., Rodrigues, T. L., Silverio, K. G., Carvalho, M. D., Nociti, F. H., et al. (2011). Autologous periodontal ligament cells in the treatment of class II furcation defects: a study in dogs. J. Clin. Periodontol. 38, 491-498. doi: 10.1111/j.1600-051X.2011.01715.x

Takedachi, M., Sawada, K., Yamamoto, S., Ozasa, M., Shimabukuro, Y., Kitamura, M., et al. (2013). Periodontal tissue regeneration by transplantation of adipose tissue-derived stem cells. J. Oral Biosci. 55, 137-142. doi: 10.1016/j.job.2013.04.004

Tan, Z., Zhao, Q., Gong, P., Wu, Y., Wei, N., Yuan, Q., et al. (2009). Research on promoting periodontal regeneration with human basic fibroblast growth factormodified bone marrow mesenchymal stromal cell gene therapy. Cytotherapy 11, 317-325. doi: 10.1080/14653240902824757

Tobita, M., Uysal, C. A., Guo, X., Hyakusoku, H., and Mizuno, H. (2013). Periodontal tissue regeneration by combined implantation of adipose tissuederived stem cells and platelet-rich plasma in a canine model. Cytotherapy doi: 10.1016/j.jcyt.2013.05.007. [Epub ahead of print].

Tsumanuma, Y., Iwata, T., Washio, K., Yoshida, T., Yamada, A., Takagi, R., et al. (2011). Comparison of different tissue-derived stem cell sheets for periodontal regeneration in a canine 1-wall defect model. Biomaterials 32, 5819-5825. doi: 10.1016/j.biomaterials.2011.04.071

van der Sanden, B., Dhobb, M., Berger, F., and Wion, D. (2010). Optimizing stem cell culture. J. Cell. Biochem. 111, 801-807. doi: 10.1002/jcb. 22847

Warnke, P. H., Humpe, A., Strunk, D., Stephens, S., Warnke, F., Wiltfang, J., et al. (2013). A clinically-feasible protocol for using human platelet lysate and mesenchymal stem cells in regenerative therapies. J. Craniomaxillofac. Surg. 41, 153-161. doi: 10.1016/j.jcms.2012.07.003

Washio, K., Iwata, T., Mizutani, M., Ando, T., Yamato, M., Okano, T., et al. (2010). Assessment of cell sheets derived from human periodontal ligament cells: a pre-clinical study. Cell Tissue Res. 341, 397-404. doi: 10.1007/s00441-010$1009-1$

Wei, N., Gong, P., Liao, D., Yang, X., Li, X., Liu, Y., et al. (2010). Auto-transplanted mesenchymal stromal cell fate in periodontal tissue of beagle dogs. Cytotherapy 12, 514-521. doi: 10.3109/14653241003709702

Wong, R. S. (2011). Mesenchymal stem cells: angels or demons? J. Biomed. Biotechnol. 2011:459510. doi: 10.1155/2011/459510

Wu, Y., Chen, L., Scott, P. G., and Tredget, E. E. (2007). Mesenchymal stem cells enhance wound healing through differentiation and angiogenesis. Stem Cells 25, 2648-2659. doi: 10.1634/stemcells.2007-0226

Yamada, Y., Ueda, M., Hibi, H., and Baba, S. (2006). A novel approach to periodontal tissue regeneration with mesenchymal stem cells and platelet-rich plasma using tissue engineering technology: a clinical case report. Int. J. Periodontics Restorative Dent. 26, 363-369. 
Yang, Y., Rossi, F. M., and Putnins, E. E. (2010). Periodontal regeneration using engineered bone marrow mesenchymal stromal cells. Biomaterials 31, 8574-8582. doi: 10.1016/j.biomaterials.2010.06.026

Yoshida, T., Washio, K., Iwata, T., Okano, T., and Ishikawa, I. (2012). Current status and future development of cell transplantation therapy for periodontal tissue regeneration. Int. J. Dent. 2012, 307024. doi: 10.1155/2012/ 307024

Conflict of Interest Statement: The authors declare that the research was conducted in the absence of any commercial or financial relationships that could be construed as a potential conflict of interest.
Received: 13 September 2013; paper pending published: 05 October 2013; accepted: 19 October 2013; published online: 15 November 2013.

Citation: Trofin EA, Monsarrat P and Kémoun P (2013) Cell therapy of periodontium: from animal to human? Front. Physiol. 4:325. doi: 10.3389/fphys.2013.00325

This article was submitted to Craniofacial Biology, a section of the journal Frontiers in Physiology.

Copyright (c) 2013 Trofin, Monsarrat and Kémoun. This is an open-access article distributed under the terms of the Creative Commons Attribution License (CC BY).

The use, distribution or reproduction in other forums is permitted, provided the original author(s) or licensor are credited and that the original publication in this journal is cited, in accordance with accepted academic practice. No use, distribution or reproduction is permitted which does not comply with these terms. 